\title{
Correlation and Linear Regression Analysis (CALRA): A Predictive Decision Support System for LEAE
}

\author{
Domingo V. Origines $\mathrm{Jr}^{1}$, Dr. Meliza P. Alo ${ }^{2}$ \\ Information Technology Department, SPAMAST, \\ Matti, Digos, Davao Del Sur, Philippines ${ }^{1}$ \\ Professor, Graduate School, Southern Philippines, Agri-business, Marine, and Aquatic \\ School of Technology (SPAMAST), Matti, Digos, Davao Del Sur, Philippines ${ }^{2}$
}

\begin{abstract}
This study introduce a Decision Support System called Correlation and Linear Regression Analysis Decision Support System (CALRA-DSS) System. The CALRA-DSS will use Data mining technique in the process of discovering knowledge which in turn can be used to predict future results. CALRA-DSS predicts Students chances whether passed or Failed in the LEAE Licensure Examination. The integration of Data Mining Technique using Pearson-Product Moment Correlation that is used to determine the degree to which two variables are related and Regression Analysis that is used to examine the relationship between and one dependent and one independent variable. The data to be tested by this CALRA-DSS were the April 2016 Agricultural Engineering graduates of ICET, SPAMAST- Digos Campus who participated in the LEAE Mock Board Examination last and took the August 2016 LEAE. The academic records of these graduates were taken from the SPAMAST Electronic Students Information System (eSMS) Digos Campus while the Mock Board data Result was taken from the SPAMAST LEAE Reviewer Committee. It is concluded that with the use of this tool, the ICET Department can implement an intervention program timely before Student would intend to take the LEAE. Based on the Outcome, the results obtained from the Correlation and Regression Analysis and the attributes obtained from eSMS, the identified Academic Predictors has a strong correlation to Mock Board Examination. In general outcome of the study can give a hint to the Students as to which subjects can be considered as predictor variables for their licensure exam scores and hence become their focus of study/review while still studying.
\end{abstract}

Keywords: Correlation, Data Mining, Regression, LEAE, Academic Performance, Prediction.

\section{INTRODUCTION}

Decision support systems (DSS) are defined as interactive application systems intended to help decision makers utilize data and models in order to identify problems, solve problems and make decisions. The mission of decision support systems is to improve effectiveness, rather than the efficiency of decisions [21]. This study introduce a Decision Support System called Correlation and Linear Regression Analysis-Decision Support System (CALRA-DSS) System, a system tool that can process and discover a knowledge which in turn can be used to predict future results. Using Academic Predictors, the CALRA-DSS can predict Students chances whether passed or Failed in the Licensure Examination. The integration of Data Mining Technique to the system using Pearson-Product Moment Correlation that is used to determine the degree to which two variables are related and Regression Analysis that is used to examine and predict the relationship between one dependent and one independent variable. Basically, regression takes a numerical dataset and develops a mathematical formula that fits the data. After performing an analysis, the regression statistics used to predict the dependent variable when the independent variable is known [6]. The integration allows the use of more than one input variable and allows for the fitting of more complex models basis for Decision Support System that strongly predicts the relationship between academic variables and result in the Mock Board Examination[9].

In an Academic Institution using Decision Support System, there are several ways of defining the quality of higher education institutions (HEI) in the Philippines. One tangible measure commonly used in the country is the performance of an HEI's graduates in state licensure examinations [7]. There have been several attempts to discover models in predicting the performance in licensure examination but most studies recommend for an extensive study covering other independent variables and other approaches [8].

Garciano found out that the Academic Performance such as General Education Subjects, Agricultural Engineering (AE) Major Subjects, and $80 \%$ Score Performance on the Mock Board Examination has a strong correlation in achieving a 
Vol. 8, Issue 4, April 2019

higher level of passing rate in the Licensure Examination for Agricultural Engineering (LEAE) to the Graduates of BSAE in SPAMAST [1]. It was also significantly revealed by Arce, S. E. and Belen, J. L. that the relationship of InHouse review to LET performance using descriptive - correlational method [5] and found out that pre-board and LET results are significantly correlated.

In SPAMAST, the Licensure Exam for Agricultural Engineering is under the Institute of Computing Engineering and Technology (ICET). One of the pressing concerns of the ICET of the Southern Philippines Agri-business and Aquatic and School of Technology (SPAMAST) is the batting or passing percentage of its graduates in the Licensure Examination for Agricultural Engineering (LEAE)[1]. Based on the licensure examination result from Philippine Regulation Commission (PRC), SPAMAST has experienced low performance in Agricultural Engineering Board Program offered from 2006 up to Present. In order to improve and increase the Passing Percentage for the LEAE in SPAMAST, A User-friendly tools in predicting the Students chances whether passed or Failed in the Licensure Examination must be utilized by the ICET Department so that the ICET could Implement timely an intervention program before the Students would take the Licensure Examination.

\section{REVIEW OF RELATED LITERATURE}

Several reform agenda and programs have been initiated to set directions for State Universities and Colleges (SUCs) for them to catch up with top universities and colleges in other ASEAN countries. Among these are the Philippine Development Plan 2011-2016; Public Higher Education Reform Agenda issued in 2012; the criteria in evaluating the performance of SUC under Executive Order (EO) No. 80, s. 2012; and CHED Memorandum Order (CMO) No. 46, s. 2012 on typology and outcomes-based quality assurance. The results of these initiatives should now be quantifiable in terms of the performance of issues in the areas of quality and relevance of instruction, research capability and output, services to the community, and management of resources [7].

The 113 SUCs are at various stages of development. Many of them have outgrown their levels both quantitatively and qualitatively. Thus, there is a need to conduct another leveling exercise to determine the current status of SUCs and to level the playing field with private higher education institutions (HEIs). I . The Fiscal Year (FY) 2016 leveling instrument for SUCs has been prepared jointly by the CHED and the DBM, in coordination with the PASUC. One of the Indicators for SUC Leveling is the Performance of Licensure Examination on Board Programs being offered by the SUCs [7].

There are several ways of defining the quality of higher education institutions (HEI) in the Philippines. One tangible measure commonly used in the country is the performance of an HEI's graduates in state licensure examinations. Through these examinations, the skills, and competencies which are said to be the likely outputs of a quality-assured HEI could be measured to some extent basis for SUC's leveling [2].

BS in Agricultural Engineering is a five-year program that concentrates on the technical aspect of Agriculture. Its curriculum revolves around the application of engineering principles in the production, processing, handling and storage of food, fiber, and materials. It also covers areas such as irrigation and drainage of agricultural land, soil erosion control, the planning of agricultural buildings and structures, post-harvest technology and agricultural waste management. It has a board examination. The subjects in the BSAE curriculum are divided into the following categories: General Education courses, Fundamental Agricultural courses, Basic Engineering courses and Professional courses[2][7].

To become a Licensed Agricultural Engineer in the Philippines, a graduate of BS in Agricultural Engineering needs to pass the Agricultural Engineer Licensure Examination. The examination is conducted by the Board of Agricultural Engineering under the supervision of the Professional Regulations Commission (PRC). The exam is conducted once a year [2][7].

The PRC Licensure examination for Agricultural Engineers (LEAE) covers the following subjects. Thirty Percent (30\%) for Subject 1 covers topics in Agricultural mechanization, Power Machinery, and Equipment. Another thirty percent $(30 \%)$ for Subject 2 which covers Soil and Water Conservation, Irrigation and Drainage and another forty percent $(40 \%)$ for subject 3 which covers concerning Rural Electrification, Agricultural Processing and Agricultural Statistics [2].

There have been several attempts to discover models in predicting the performance in licensure examination but most studies recommend for an extensive study covering other independent variables and other approaches [8]. A Data Mining Technique is a way to discover new meaning in data, perform data processing using sophisticated data search capabilities and statistical algorithms, which can be utilized in any organization or system that needs to determine the patterns or relationship implicit in a large data warehouse for better strategies to best reach them[6]. Data Mining was originally developed to act as expert systems to solve problems and did not require assumptions to be made about data[8].

Hand et al, cited that in a real world, predicting the performance of the students is a challenging task. The primary goals of Data Mining in practice tend to be Prediction and Description. Predicting performance involves variables like Math, Programming language, Lab Marks etc. in the student database to predict the unknown or future values of interest. Educational Data Mining uses many techniques such as Correlation, Regression, Decision Trees, MultiLayer perception 
NaïveBayes and many others. Using these methods many kinds of knowledge can be discovered[14].

Lee and Park presented the Customized Sampling Decision Support System (CSDSS) which uses data mining [12]. CSDSS is a web-based system that enables the user to select a process sampling method that is most suitable according to his needs at purchasing semiconductor products. The system enables the autonomous generation of the available customized sampling methods and provides the performance information for those methods. CSDSS uses clustering data mining method within the generation of sampling methods.

Zupan et al., also tried to bridge the data mining and decision support in their study. Specifically, they proposed a mechanism for communicating data mining models. The predictive model was developed separately within a data mining tool which is called Orange, then the model is encoded in XML [18] hence, models are hard coded and fixed. Baking and Quimbao introduced the same concept by proposing a knowledge-driven educational decision support system for education with a semester credit system by taking advantage of educational data mining [5]. This is, however, different from this paper's objective though it was considered to be in the educational context.

Meanwhile, Mock Examinations defined as one of the predictors that influenced the performance of Education Graduates [9]. Bachelor of Science in Basic Education Graduates of the University of the Cordilleras have been studied through undergoing mock examination in the L.E.T. Imitating the actual examination, College of Education Faculty organized the comprehensive examination and it has found out that respondents gained positive impact of the said examination in their performance. It has been recommended to continually conduct comprehensive or mock examinations to education graduates before taking Licensure Examination for Teachers to increase their probability in passing the board examination [10].

Arce, S. E. and Belen, J. L. undertook a study that revealed the relationship of In-House review to LET performance using descriptive - correlational method [5] and found out that pre-board and LET results are significantly correlated.

On the other hand, the profile of respondents, the level of motivation, gender, race and career preferences are personal factors that serve as the strong determinants of Board Examination Performance [19], and (17). Mental and Psychological enhancement of education graduate through a high level of motivation, perseverance; determination and influence by the institution to pass the board examination have been shaped as one of the strong factors affecting Licensure Examination for Teachers. Based on the study conducted by [19] in University of Northern Philippines, female respondents achieved a higher level of passing rate in board examination and most of them came from Music, Arts, Physical Education and Health (MAPEH) major and examinees' Grade Point average ranged from 2.00-2.25. Likewise, institutions that achieved high level of passing rate serves as the influential factor in the personalities of examinees to pass the board examination [19][17].

Previous studies have indicated that by and large, performance of Education Graduates in Licensure Examination for Teachers is shaped both by personal and educational factors. As an evidence, a study conducted by Filipino researchers have been found that academic performance in terms of Specialization (Computer Education, English, Filipino, Mathematics, Science and Social Studies), General Education (Social Sciences, Mathematics, Science, Filipino and English) and Professional Education serves as the strong predictor of Board Examination Performance [19], [4],and [10]. Also, Admission Test, Degree Course, English Proficiency and Institutional Passing rate of Education Graduates are the factors affecting with the effectiveness of education respondents in Licensure Examination for Teachers [19]. Teaching factors and implemented policies of In-house review conducted by universities and review center are the factors that largely affect their board examination performance [20] .

All the above-cited works gave credit to the importance of integrating decision support system and data mining. So far, it was undertaken that focus on student records as a Predictors basis for DSS will lead to a good Passing Performance rate for future Student Licensure Examination.

III. THEORETICAL FRAMEWORK

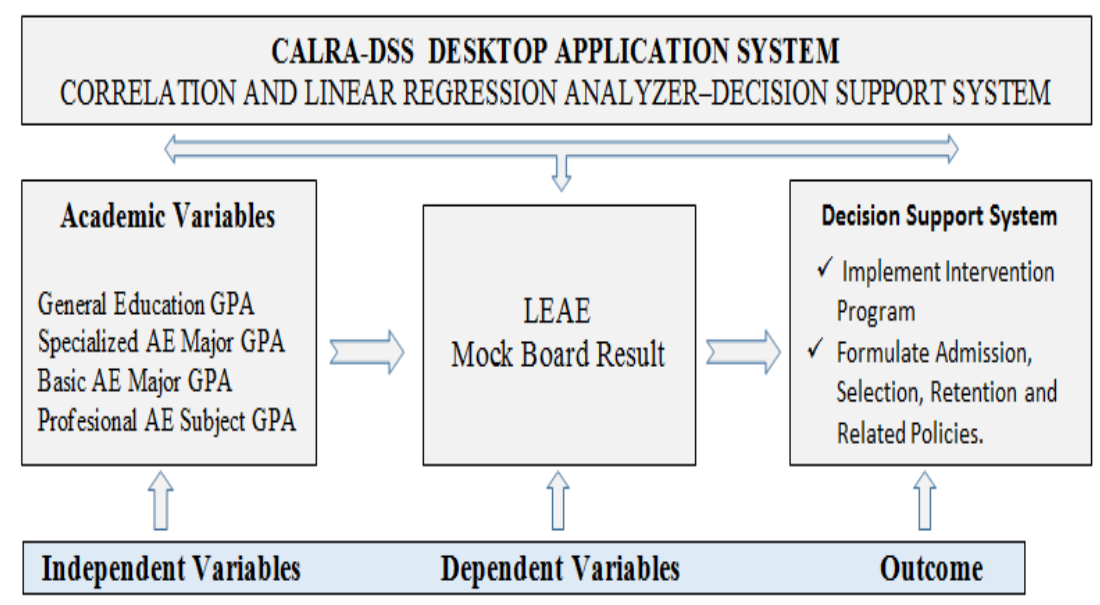

Figure 1. Conceptual Framework 
Vol. 8, Issue 4, April 2019

Figure 1 shows the Conceptual Framework of the Study. The GPA for General Education, Specialized AE Major, Professional Courses and Basic AE Subject Courses are the Independent Variables while Mock Board Examination Result is the Dependent Variables. The Independent and Dependent Variables would be the basis for the Decision Support System as Outcome variable. The Independent, Dependent and Outcome Variables are the components of CALRA-DSS Desktop Application System.

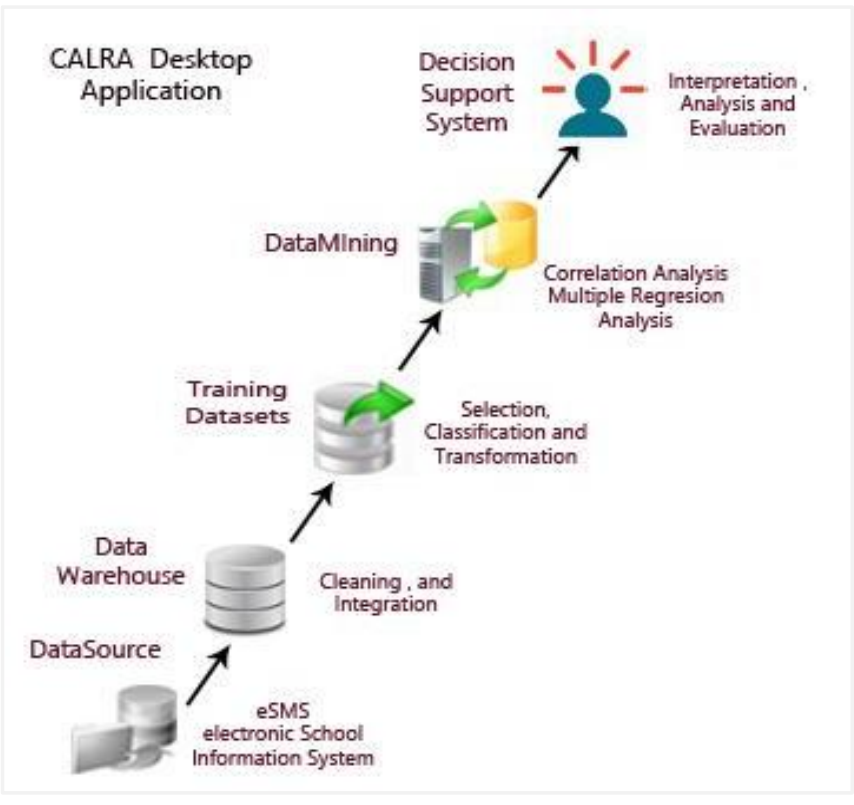

Figure 2. Data Mining Framework

Figure 2 shows the Data Mining Framework. It follows from Data Sources which will perform downloading of Data from eSMS, Data Warehouse which will perform Cleaning and Integration, Training Datasets which will do the Selection, Classification and Transformation, Training Datasets which will perform Correlation and Regression Analysis, and Decision Support System of which the System User will do Interpretation, Analysis and Evaluation.

\section{OPERATIONAL FRAMEWORK}

\section{Methodology}

The data to be tested by this CALRA-DSS were the April 2016 Agricultural Engineering graduates of ICET, SPAMAST- Digos Campus who participated in the LEAE Mock Board Examination last July 2016 and took the August 2016 LEAE. The academic records of these graduates were taken from the SPAMAST Electronic Students Information System (eSMS) Digos Campus while the Mock Board data Result was taken from the SPAMAST LEAE Reviewer Committee. These data that were stored in different tables were uploaded and cleaned by removing duplicate records. Records that contain empty values were likewise deleted. The integration was done to the different tables into one data warehouse, the data of which were transformed to create meaningful groups within the attributes to match that of the objectives of the study. The Datasets uploaded from the eSMS to CALRA-DSS were categories according to General Education Subjects (GPA_GenEd), Basic Agricultural Engineering Subjects (GPA_Basic), Professional Engineering Subjects (GPA_Prof) and Specialized Major Core Subjects (GPA_Special).

Specifically, the CALRA-DSS system has the following functionalities:

I. The system had an option to Connect to the eSMS Software and Download the Student Grades Data. It has also an option to upload Data in the form of text files or excel files.

II. The downloaded Data will categorized according to the following classification Attributes: GPA_GenEd, GPA_Basic, GPA_Major, and GPA_Special.

III. $\quad$ The System User Administrator can Create a Mock Board Questionnaire and the functionality to Generate and Compute a Summary Results per individual Student Takers.

IV. The CALRA-DSS can generate Correlation Analysis and Regression Analysis based on the Record set downloaded and Classified per Individual Recordset. 
Vol. 8, Issue 4, April 2019

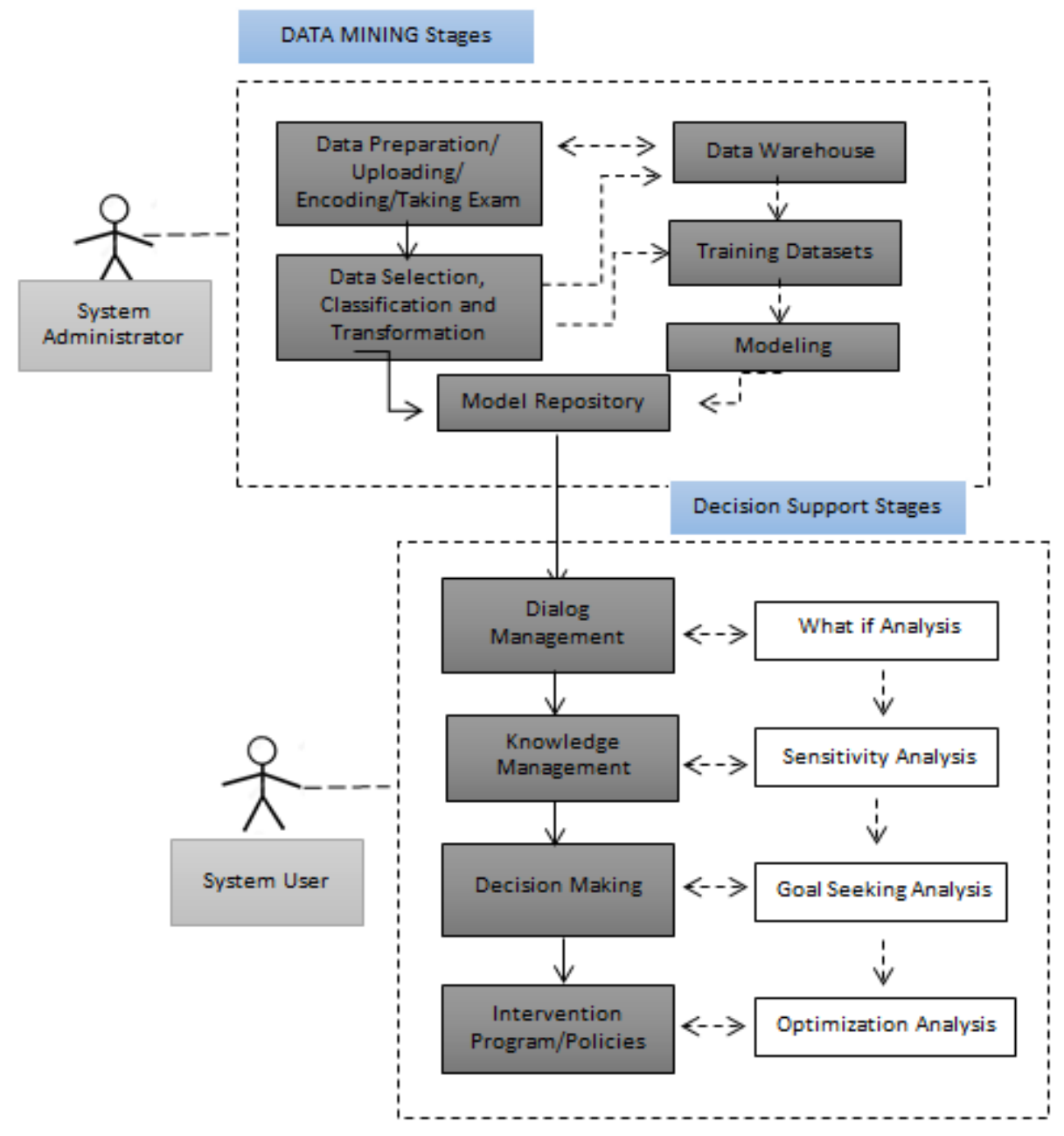

Figure 3. Process Model for Data Mining and Decision Support System

Figure 3 Show the process model for Data Mining and Decision Support System. It has two Stages the Data Mining Stages consist of Data Preparation and Uploading for Data Warehousing on Training Datasets that will produce Modeling into the Modeling Repository basis for Decision Support System. The Decision Support Stage consist of Dialogue Management of which what if analysis should be done, Knowledge Management which need sensitivity analysis, decision making that needs goal seeking analysis and Intervention on Program/Policies that needs optimization analysis. 


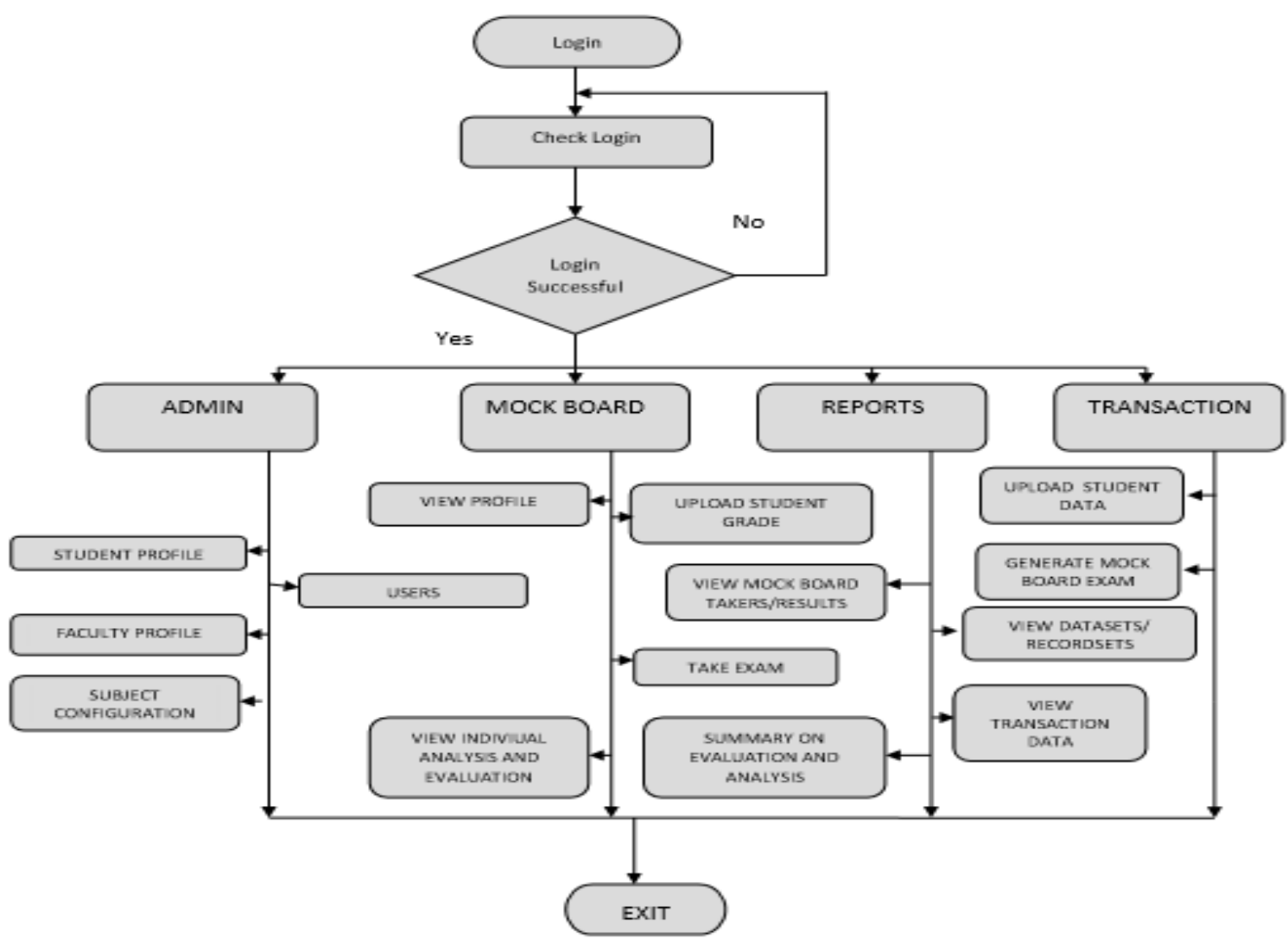

Figure 4. Data Flow Diagram

The Data Flow Diagram of CALRA-DSS. The System User needs to log-in, after validated by the system the Main Interface will appear. The Main Interface has Admin Menu, Mock Board Menu, Reports Menu and Transaction Menu as show in figure 4.

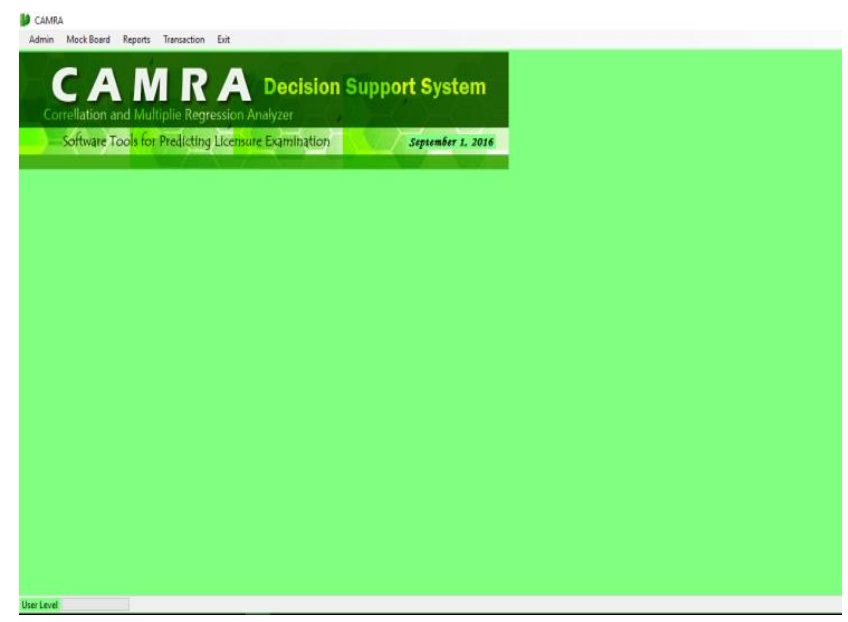

Figure 5. Main Interface for CALRA-DSS

Figure 5 shows the Main Interface for CALRA-DSS. It has Admin Menu that has sub menu for Student Profile, Subject configuration, and User Data. The Mock Board Menu has sub-menu for Take Exam, User Profile, and Individual Summary Result. The Report Menu has sub-menu for View Mock Reports, Summary, Summary on Board Questionnaire, and Individual Summary Results. The Transaction Menu has Upload Data and Generate Mock Board sub-menu. 


\section{TESTING AND SIMULATION}

\section{Correlation Analysis using Pearson Correlation Coefficient}

A Correlation Analysis using Pearson-Product Moment Correlation (r) was integrated to the CALRA-DSS to determine the relationship between identified Academic Variables and Result in the Mock Board Examination for Agricultural Engineering Students.

In order to determine how strong the relationship is between two variables, a formula must be followed to produce what is referred to as the coefficient value. The coefficient value can range between -1.00 and 1.00 . If the coefficient value is in the negative range, then that means the relationship between the variables is negatively correlated, or as one value increases, the other decreases. If the value is in the positive range, then that means the relationship between the variables is positively correlated, or both values increase or decrease together. The formula for conducting the Pearson correlation coefficient value [3].

The Datasets that is obtained from eSMS Software and generally converted into Percentage Equivalent as shown in Table 1 , so that further calculations can be made on the data and it becomes easy to handle.

TABLE 1. NUMERICAL PERCENTAGE RANGE OF PREDICTORS

\begin{tabular}{|l|l|l|}
\hline \multicolumn{1}{|c|}{$\begin{array}{c}\text { GPA Range per } \\
\text { Predictors }\end{array}$} & \multicolumn{1}{c|}{$\begin{array}{c}\text { Percentage } \\
\text { Equivalence }\end{array}$} & \multicolumn{1}{|c|}{ Qualitative Rating } \\
\hline $1.0-1.24$ & $99-100$ & Excellent \\
\hline $1.25-1.4$ & $96-98$ & Outstanding \\
\hline $1.5-1.74$ & $93-95$ & Good Work \\
\hline 1.75 .1 .4 & $90-92$ & Satisfactory Work \\
\hline $2.0-1.74$ & $87-89$ & Average \\
\hline $2.25-1.9$ & $84-86$ & Moderately Average \\
\hline $2.5-2.24$ & $78-83$ & Moderately Low Average \\
\hline $2.75-2.4$ & $74-77$ & Low Average \\
\hline $3.0-2.74$ & $70-73$ & Passing \\
\hline
\end{tabular}

Table 1 show the GPA ranges Predictors, Percentage Equivalence and the quantitative ratings for the Academic Predictors. The Equivalence will be used in converting Decimal Point Grades into Percentage Equivalence.

TABLE 2. STUDENT GRADE DATA AS DATA SOURCE DOWNLOADED FROM ESMS SOFTWARE

\begin{tabular}{|c|c|c|c|c|c|c|c|c|}
\hline StudID & Course & $\begin{array}{l}\text { Course } \\
\text { Code }\end{array}$ & Semester & $\begin{array}{l}\text { School } \\
\text { Year }\end{array}$ & Course Description & Units & FGrade & Category \\
\hline 2012-05001 & BSAE & Eng 1 & 1st Semester & $2012-2013$ & Study and Thinking Skills & 3 & 1.75 & GPA_GenEd \\
\hline 2012-05001 & BSAE & $\begin{array}{l}\text { Physics } \\
1 \mathrm{a}\end{array}$ & 1st Semester & 2012-2013 & Mechanics and Heat & 3 & 2.25 & GPA_Basic \\
\hline 2012-05001 & BSAE & Chem 2a & 1st Semester & 2012-2013 & Organic Chemistry & 3 & 2.25 & $\underset{\mathrm{d}}{\text { GPA_GEnE }}$ \\
\hline 2012-05001 & BSAE & Eng 2 & 1st Semester & 2012-2013 & Writing in the Discipline & 3 & 2.25 & $\begin{array}{c}\text { GPA_GEnE } \\
\text { d }\end{array}$ \\
\hline 2012-05001 & BSAE & Fil 2 & 1st Semester & 2012-2013 & $\begin{array}{l}\text { Pagbasa at Pagsulat sa } \\
\text { Iba't-ibang Disiplina }\end{array}$ & 3 & 1.5 & $\underset{\mathrm{d}}{\text { GPA_GEnE }}$ \\
\hline 2012-05001 & BSAE & Math 3 & 1st Semester & 2012-2013 & $\begin{array}{l}\text { Analytic Geometry and } \\
\text { Calculus I }\end{array}$ & 3 & 2.25 & GPA_Basic \\
\hline 2012-05001 & BSAE & PE 2 & 1 st Semester & $2012-2013$ & Rhythmic Activities & 2 & 1.75 & GPA_GenEd \\
\hline $2012-05001$ & BSAE & NSTP 2 & 1st Semester & $2012-2013$ & LTS/CWTS/ROTC 2 & 3 & 1.5 & GPA_GenEd \\
\hline $2012-05001$ & BSAE & Hist 1 & 2nd Semester & 2013-2014 & Philippine History & 3 & 1.5 & GPA_GenEd \\
\hline $\begin{array}{l}2012- \\
05001\end{array}$ & BSAE & Hum 1 & 2nd Semester & 2013-2014 & $\begin{array}{l}\text { Introduction to } \\
\text { Humanities }\end{array}$ & 3 & 2.0 & GPA_GenEd \\
\hline
\end{tabular}

Table 2 shows the downloaded Student Grades from eSMS Software to be used as Data Source for the Academic Predictors. 
Vol. 8, Issue 4, April 2019

TABLE 2a. Average Gpa For Each Category From Data Source

\begin{tabular}{|c|c|c|c|c|c|}
\hline STUD_ID & $\begin{array}{c}\text { GPA_ } \\
\text { GenEd }\end{array}$ & $\begin{array}{c}\text { GPA_ } \\
\text { Basic }\end{array}$ & $\begin{array}{c}\text { GPA_ } \\
\text { Prof }\end{array}$ & $\begin{array}{c}\text { GPA_ } \\
\text { Special }\end{array}$ & $\begin{array}{c}\text { GPA_ } \\
\text { OverAll }\end{array}$ \\
\hline $2012-05001$ & 95 & 92 & 90 & 94 & 93 \\
\hline $2012-05002$ & 86 & 85 & 85 & 87 & 86 \\
\hline $2012-05003$ & 90 & 90 & 88 & 85 & 88 \\
\hline $2012-05004$ & 80 & 82 & 81 & 79 & 81 \\
\hline $2012-05005$ & 83 & 90 & 89 & 86 & 87 \\
\hline $2012-05006$ & 87 & 88 & 84 & 92 & 88 \\
\hline $2012-05007$ & 84 & 82 & 83 & 86 & 84 \\
\hline $2012-05008$ & 71 & 73 & 75 & 77 & 74 \\
\hline $2012-05009$ & 70 & 72 & 77 & 75 & 74 \\
\hline $2012-05010$ & 77 & 79 & 76 & 79 & 78 \\
\hline
\end{tabular}

Table 2a shows the Average GPA for each Category downloaded from Data Source. It is now transformed by the CALRA-DSS System into Percentage equivalent per Category.

Table 2b. Result from Student Mock Board Examination per Category

\begin{tabular}{|c|c|c|c|c|c|}
\hline STUD_ID & $\begin{array}{c}\text { GenEd_- } \\
\text { Result }\end{array}$ & $\begin{array}{c}\text { Basic_- } \\
\text { Result }\end{array}$ & $\begin{array}{c}\text { Prof_- } \\
\text { Result }\end{array}$ & $\begin{array}{c}\text { Special_ } \\
\text { Result }\end{array}$ & $\begin{array}{c}\text { Avg_Mock } \\
\text { Board Result }\end{array}$ \\
\hline $2012-05001$ & 90 & 90 & 91 & 97 & 92 \\
\hline $2012-05002$ & 87 & 84 & 85 & 88 & 86 \\
\hline $2012-05003$ & 89 & 86 & 88 & 87 & 88 \\
\hline $2012-05004$ & 67 & 66 & 80 & 80 & 73 \\
\hline $2012-05005$ & 88 & 88 & 89 & 88 & 88 \\
\hline $2012-05006$ & 84 & 86 & 84 & 87 & 85 \\
\hline $2012-05007$ & 88 & 81 & 83 & 86 & 85 \\
\hline $2012-05008$ & 45 & 56 & 76 & 67 & 61 \\
\hline $2012-05009$ & 78 & 71 & 72 & 76 & 74 \\
\hline $2012-05010$ & 56 & 55 & 59 & 60 & 58 \\
\hline
\end{tabular}

Source: Result Mock Board Examination last May 2016 from SPAMAST Review Center.

Table $2 \mathrm{~b}$ shows the Average GPA Mock Board for each Category gathered from SPAMAST Review Center last May 2016.

Table 3. Consolidated GPA_Overall and Average Mock board Result

\begin{tabular}{|c|c|c|}
\hline STUD_ID & GPA_OverAll & AVG_MockBoard Result \\
\hline $2012-05001$ & 93 & 92 \\
\hline $2012-05002$ & 86 & 86 \\
\hline $2012-05003$ & 88 & 88 \\
\hline $2012-05004$ & 81 & 73 \\
\hline $2012-05005$ & 87 & 88 \\
\hline $2012-05006$ & 88 & 85 \\
\hline $2012-05007$ & 84 & 85 \\
\hline $2012-05008$ & 74 & 61 \\
\hline $2012-05009$ & 74 & 74 \\
\hline $2012-05010$ & 78 & 58 \\
\hline
\end{tabular}

Table 3 shows the consolidated result from GPA_Overall as Independent Variables and AVG Mock Board Result as Dependent Variables. 
International Journal of Advanced Research in Computer and Communication Engineering

Vol. 8, Issue 4, April 2019

\section{TESTING FOR CORRELATION ANALYSIS}

Table 4 shows the Predictors data for two variables, labeling the variables $(x)$ and $(y)$, and add three more columns labeled $(x y),\left(x^{\wedge} 2\right)$, and $\left(y^{\wedge} 2\right)$.

Table 4. Combined Datasets for GPA_OverAll and Mock Board Result as x and y Variables

\begin{tabular}{|c|c|c|c|c|c|}
\hline STUD_ID & $\begin{array}{l}\mathrm{GPA}_{-} \\
\text {OverAll } \\
(\mathrm{y})\end{array}$ & $\begin{array}{l}\text { AVG__Mock }_{-} \text {Board Result } \\
\text { (x) }\end{array}$ & xy & $x^{2}$ & $\mathrm{y}^{2}$ \\
\hline 2012-05001 & 93 & 92 & 8,533 & 8,464 & 8,603 \\
\hline 2012-05002 & 86 & 86 & 7,375 & 7,396 & 7,353 \\
\hline $2012-05003$ & 88 & 88 & 7,722 & 7,656 & 7,788 \\
\hline 2012-05004 & 81 & 73 & 5,897 & 5,366 & 6,480 \\
\hline $2012-05005$ & 87 & 88 & 7,678 & 7,788 & 7,569 \\
\hline $2012-05006$ & 88 & 85 & 7,481 & 7,268 & 7,700 \\
\hline 2012-05007 & 84 & 85 & 7,077 & 7,140 & 7,014 \\
\hline $2012-05008$ & 74 & 61 & 4,514 & 3,721 & 5,476 \\
\hline $2012-05009$ & 74 & 74 & 5,457 & 5,513 & 5,402 \\
\hline $2012-05010$ & 78 & 58 & 4,471 & 3,306 & 6,045 \\
\hline$\sum$ & 831 & 790 & 66,203 & 63,618 & 69,430 \\
\hline
\end{tabular}

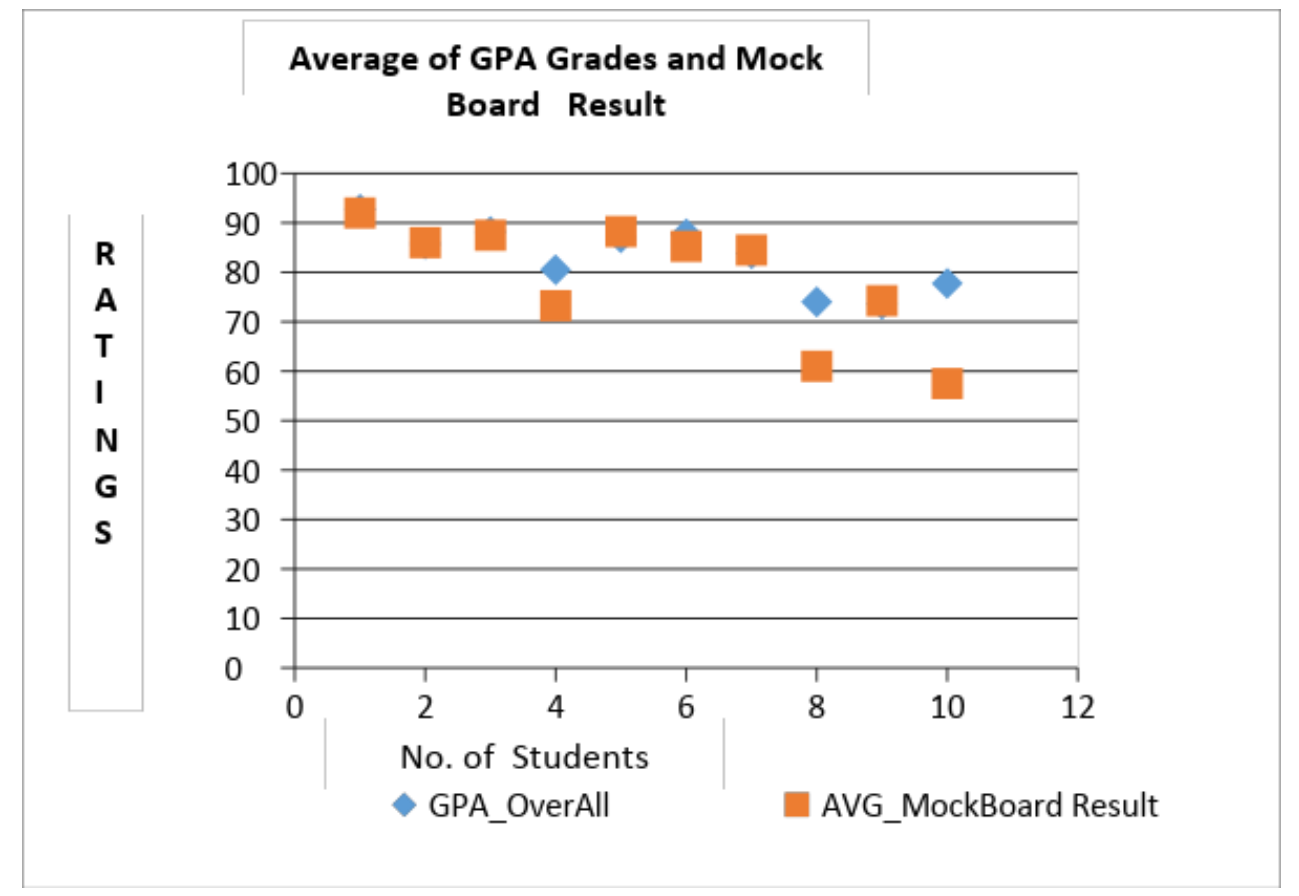

Figure 6. Scatter Plot for $\mathrm{x}$ and $\mathrm{y}$ Variables

The correlation coefficient formula is as follows:

$(\mathrm{r})=[\mathrm{n} \Sigma \mathrm{xy}-(\Sigma \mathrm{x})(\Sigma \mathrm{y}) / \operatorname{Sqrt}([\mathrm{n} \Sigma \mathrm{x} 2-(\Sigma \mathrm{x}) 2][\mathrm{n} \Sigma \mathrm{y} 2-(\Sigma \mathrm{y}) 2])]$

$\mathrm{r}$ : The correlation coefficient is denoted by the letter $\mathrm{r}$.

$\mathrm{n}$ : Number of values. If we had ten(10) people we were calculating the correlation coefficient for, the value of $\mathrm{n}$ would be 10 .

$\mathrm{x}$ : This is the first data variable.

$\mathrm{y}$ : This is the second data variable.

$\Sigma$ : The Sigma symbol (Greek) tells us to calculate the "sum of" whatever is tagged next to it. 
Vol. 8, Issue 4, April 2019

Pearson's Correlation Coefficient is a linear correlation coefficient that returns a value of between -1 and +1 . A -1 means there is a strong negative correlation and +1 means that there is a strong positive correlation. A 0 means that there is no correlation (this is also called zero order correlation).

Table 5. Range of P interpretation

\begin{tabular}{|l|l|}
\hline \multicolumn{1}{|c|}{ Value of $\boldsymbol{\rho}$} & \multicolumn{1}{|c|}{ Strength of relationship } \\
\hline-1.0 to -0.5 or 1.0 to 0.5 & Strong \\
\hline-0.5 to -0.3 or 0.3 to 0.5 & Moderate \\
\hline-0.3 to -0.1 or 0.1 to 0.3 & Weak \\
\hline-0.1 to 0.1 & None or very weak \\
\hline
\end{tabular}

Formula for Correlation Coefficient and Result:

$$
\begin{aligned}
& r=\frac{n \sum x y-\sum x \sum y}{\sqrt{\left[n\left(\sum x^{2}\right)-\left(\sum x\right)^{2}\right]\left[n\left(\sum y^{2}\right)-\left(\sum y\right)^{2}\right]}} \\
& \text { where: } \\
& =\frac{10(66,203)-(790)(831)}{\sqrt{\left[10(63,618)-(790)^{2}\right]\left[10(69,430)-(831)^{2}\right]}} \\
& =0.856
\end{aligned}
$$

Table 6. Using Microsoft Excel (Excel Correlation Output)

\begin{tabular}{|l|r|r|}
\hline & GPA_OverAll & \multicolumn{1}{|c|}{ AVG_MockBoard Result } \\
\hline GPA_OverAll & 1 & \\
\hline AVG_MockBoard Result & 0.858549994 & 1 \\
\hline
\end{tabular}

The formula above shows that after plugging in all the correct values, the result is the coefficient value! If the value is a negative number, then there is a negative correlation of relationship strength, and if the value is a positive number, then there is a positive correlation of relationship strength as shown in Table 6.

Figure 6 shows the Scatter Plot for GPA_OverAll and AVG MockBoard Result Examination. It also shows from Table 6, the Computed Data using the Pearson correlation coefficient value from the formula below. Result shows from the Formula and Table 5 as result done in Excel Correlation Output, that there is a relatively strong positive linear association between $\mathrm{x}$ and $\mathrm{y}$ variables, meaning the null hypotheses is rejected.

To do the other test with regards to the null hypothesis, H0, that there is no correlation in the population against the alternative hypothesis, H1, that there is correlation; our data will indicate which of these opposing hypotheses is most likely to be true. We can thus express this test as:

Significance Test for Correlation

$$
\mathrm{t}=\frac{\mathrm{r}}{\sqrt{\frac{1-\mathrm{r}^{2}}{\mathrm{n}-2}}}
$$

- Hypotheses

$$
\begin{array}{ll}
\mathrm{Ho}_{0}: \rho=0 & \text { (no correlation) } \\
\mathrm{HA}: \rho \neq 0 & \text { (correlation exists) }
\end{array}
$$

- Test statistic

- (with $\mathrm{n}-2$ degrees of freedom)

Hypotheses: $\quad$ There is no significant relationship between identified academic Variables and Performance in the Mock Board examination

Result:

$$
\mathrm{t}=\frac{\mathrm{r}}{\sqrt{\frac{1-\mathrm{r}^{2}}{\mathrm{n}-2}}}=\frac{.856}{\sqrt{\frac{1-.856^{2}}{10-2}}}=4.887
$$

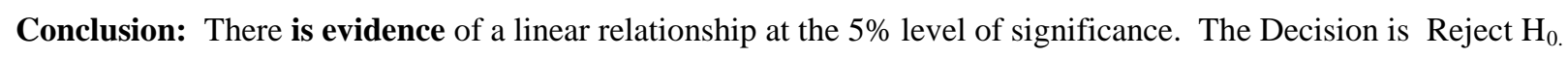




\section{A. REGRESSION ANALYSIS}

The Regression Analysis predicts the value of a dependent variable based on the value of at least one independent variable. In this Regression Analysis the Data from Table 4 was used as x and y Variables. The formula for Regression Analysis is shown in below.

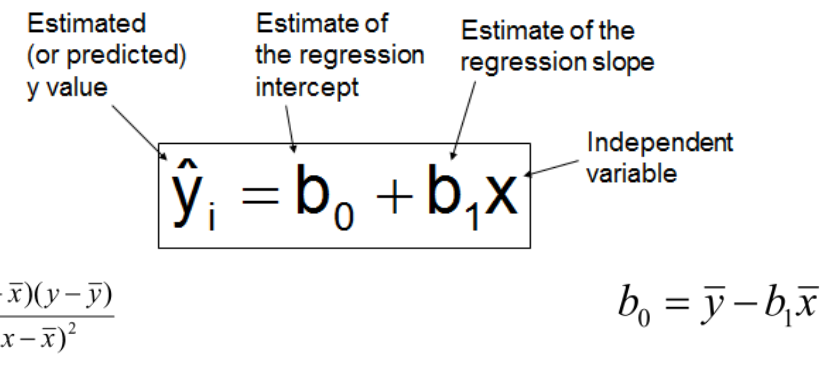

Figure 7. Regression Analysis Formula

$\mathrm{b}_{0}$ is the estimated average value of $\mathrm{Y}$ when the value of $\mathrm{X}$ is zero (if $\mathrm{x}=0$ is in the range of observed $\mathrm{x}$ values)

Using the Microsoft Excel for testing, the coefficients $b_{0}$ is the regression intercept while $b_{1}$ is the slope. The Table 7 shows the Summary Output on Regression Analysis using Data from Table 4 using MockBoard Result as x Variable and GPA_OverAll as y Variables.

\begin{tabular}{|l|r|}
\hline \multicolumn{2}{|c|}{ Regression Statistics } \\
\hline Multiple R & 0.858549994 \\
\hline R Square & 0.737108092 \\
\hline Adjusted R Square & 0.704246604 \\
\hline Standard Error & 3.507026318 \\
\hline Observations & 10 \\
\hline
\end{tabular}

\begin{tabular}{|c|c|c|c|c|c|}
\hline \multicolumn{4}{|l|}{ ANOVA } & \multirow[b]{2}{*}{$F$} & \multirow[b]{2}{*}{$\begin{array}{c}\text { Significanc } \\
\text { e } F\end{array}$} \\
\hline & $d f$ & $S S$ & $M S$ & & \\
\hline $\begin{array}{l}\text { Regressio } \\
\mathrm{n}\end{array}$ & 1 & 275.88113 & 275.881 & $\begin{array}{l}22.4307 \\
58\end{array}$ & 0.001471 \\
\hline Residual & 8 & 98.393869 & 12.2992 & & \\
\hline Total & 9 & 374.275 & & & \\
\hline
\end{tabular}

\begin{tabular}{lccrr}
\hline & Coefficients & $\begin{array}{c}\text { Standard } \\
\text { Error }\end{array}$ & t Stat & \multicolumn{1}{c}{ P-value } \\
\hline Intercept & 46.546575 & 7.797295 & 5.96958 & 0.0003354 \\
AVG_MockBoard & & & & \\
Result & 0.46299462 & 0.0977584 & 4.73611 & 0.001473 \\
\hline & Lower 95\% & Upper 95\% & Lower 95.0\% & Upper 95.0\% \\
\cline { 2 - 5 } & 28.56598 & 64.52717 & 28.566 & 64.527 \\
& 0.2375634 & 0.6884258 & 0.23756 & 0.6884 \\
\hline
\end{tabular}

Given the Result Summary as shown in Table 7, the Estimated Regression Formula derived from the Regression Summary output will have the values below:

\section{AVG_MockBoard Result $=46.54657482+0.462994619($ GPA_OverALL $)$}

$\mathrm{b}_{1}$ measures the estimated change in the average value of $\mathrm{Y}$ as a result of a one-unit change in $\mathrm{X}$

Here, $b_{1}=.463$ tells us that the average value of a GPA_OverAll increases by .463$)=46.55$,on average, for each additional GPA_Overall Ratings. 
Vol. 8, Issue 4, April 2019

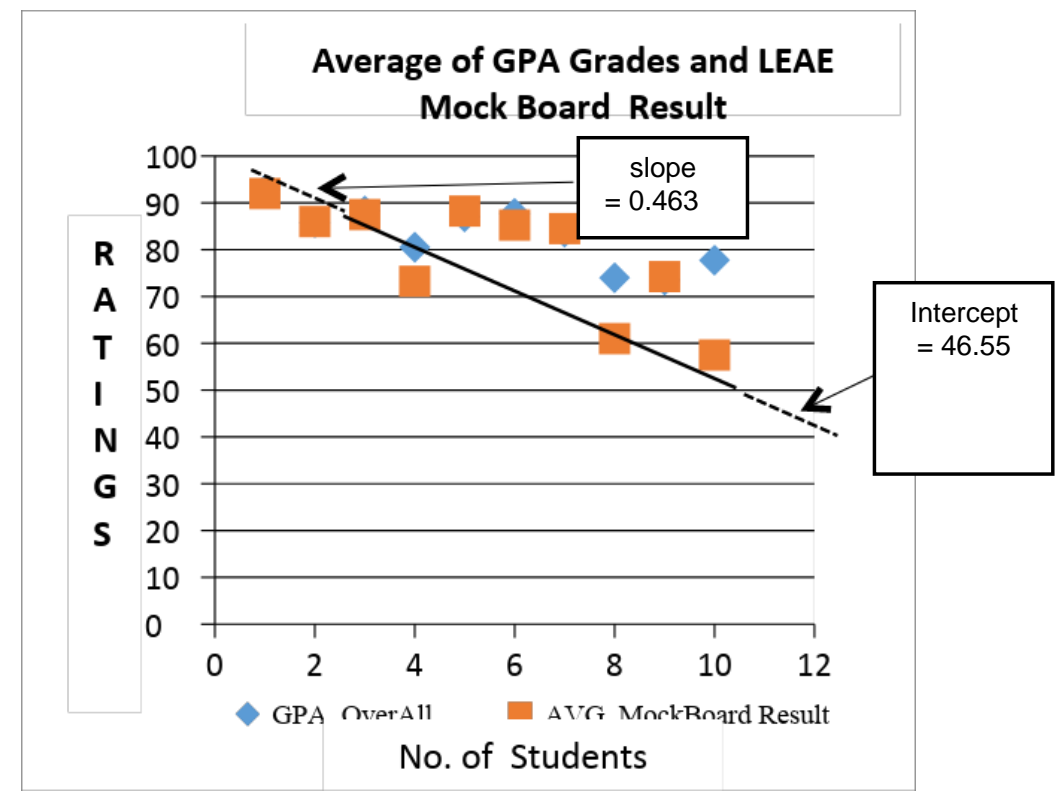

Figure 8. Scatter Plot with intercept and slope

Figure 8 shows the Scatter Plot of $\mathrm{x}$ and $\mathrm{y}$ variables. As a result Data from Table has slope of 0.463 and an intercept of 46.55 .

\section{Sample Prediction:}

Predict the Mock Board Exam of a Student with GPA_OverAll of 71 and 91

Does Percentage Ratings of GPA_OveraAll affect its Mock Board Examination Result?

Using Regression Formula, the prediction are as follows:

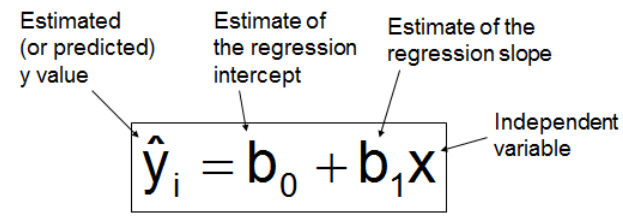

AVG_MockBoard Result $=46.54657482+0.462994619($ GPA_OverALL $)$

With a GPA_OverAll of 71:

AVG_MockBoard Result $=46.54657482+0.462994619(71)$

AVG_MockBoard Result $=46.55+32.87$

Predicted MockBoard Result:

AVG_MockBoard Result = 79.42

With a GPA_OverAll of 91:

AVG_MockBoard Result $=46.54657482+0.462994619(91)$

AVG_MockBoard Result $=46.55+42.13$

\section{Predicted MockBoard Result:}

AVG_MockBoard Result $=88.67$

As shown in the above result from the Predicted MockBoard Result. The Student who has a GPA_OverAll of 71 will have a predicted Mockboard of 79.42 which means a Moderate Chances in the Licensure Examination will be 
Vol. 8, Issue 4, April 2019

achieved while student who has the GPA_OverAll 91 will have a predicted Mockboard result of 88.67, which means a Strong Chances to Passed the Licensure Examination will be achieved. Interpretation on the Modeling and Simulation results, as presented by Garciano(2012), the CALRA-DSS will use the Table 8 matrix for Mockboard Average Ratings and the Chances on the Licensure Examination is a model to integrate in predicting the Possible Performance of Students in the Licensure Examination[1].

Table 8. Average on MockBoard Result on chances to LEAE

\begin{tabular}{|l|l|}
\hline \multicolumn{1}{|c|}{$\begin{array}{c}\text { MockBoard Average } \\
\text { Ratings }\end{array}$} & \multicolumn{1}{c|}{$\begin{array}{c}\text { Chances in the PRC Licensure } \\
\text { Examination }\end{array}$} \\
\hline $91-100$ & Very Strong \\
\hline $80-90$ & Strong \\
\hline $70-79$ & Moderate \\
\hline $50-69$ & Weak \\
\hline 49 below & Very weak \\
\hline
\end{tabular}

\section{CONCLUSION AND RECOMMENDATION}

Discussion on this Study concentrated on the Academic Predictors for Licensure Examination in Agricultural Engineering using correlation analysis Pearson-Product Moment Correlation and lienear regression analysis. The Mock Board Questionnaire generated by CALRA-DSS is focus only on the BSAE Program curricular courses provided by the SPAMAST Review Center. Based on the Outcome, the results obtained from the Correlation and Regression Analysis and the attributes obtained from eSMS, the identified Academic Predictors has a strong correlation to Mock Board Examination. A supporting tools developed by Tarun et al. (2014) and Garciano (2012) also revealed that the Mock Board Examination has a strong correlation in predicting the PRC Licensure Examination [6]. If the Academic Predictors and Mock Board Examination is good, then the reviewee is predicted to Passed. Other than the above rules, the reviewee is predicted to fail if students will not focus on the subject's per area that has a Failed result. It is concluded that with the use of this tool, the ICET Department can implement an intervention program timely before Student would intend to take the LEAE. In general outcome of the study can give a hint to the Students as to which subjects can be considered as predictor variables for their licensure exam scores and hence become their focus of study/review while still studying. Administration can also have an idea based on the correlation results on what to contribute in improving the Agricultural Engineering program. It can help also the Faculty to reevaluate their teaching strategies and subject syllabi that would fit the current need of the Agricultural Engineering students. And lastly, result summary report from CALRA-DSS can serve as a reference in terms of policy-making related to admission and selection as well as retention for the BSAE Program.

\section{REFERENCES}

[1] S. Garciano , "Correlation Analysis Between Academic Variables and Licensure Examination Performance of SPAMAST Graduates." 2012.

[2] Republic Act No. 8559. An Act Regulating the Practice of Agricultural engineering in the Philippines.

[3] L. Barton, P. Willson, R. Langford, \& Schreiner, B. "Standardized predictive testing: Practices, policies, and outcomes". Administrative Issues Journal: Connecting education, practice, and research, 4(2), 68-76.2014.

[4] S. Pachejo, and W. Allaga,. "Academic Predictors of the Licensure Examination for Teachers' Performance of the Rizal Technological University Teacher Education Graduates". International Journal of Educational Research and Technology. Retrieved from www.soeagra.Original Article com/ijert/ijert.htm.2014

[5] D. T. Quiambao, E. G. Baking, L. M. B. Buenviaje, A. V Nuqui, and R. C. Cruz, "PREDICTORS OF BOARD EXAM PERFORMANCE OF THE," vol. 1, no. 1, pp. 1-4, 2015.

[6] I. M. Tarun, B. D. Gerardo, and B. T. Tanguilig III, "Generating Licensure Examination Performance Models Using PART and JRip Classifiers: A Data Mining Application in Education,” Int. J. Comput. Commun. Eng., vol. 3, no. 3, pp. 202-207, 2014.

[7] BS in Agricultural Engineering in the Philippines, available online: http://www.finduniversity.ph/majors/bs-in-agricultural-engineeringphilippines/

[8] H. David, Mannila Heikki, and Smyth Padhraic. "Principles of Data Mining".

[9] O. Figuerres, "An Analysis of the Performance of the University of Northern Philippines in the Licensure Examination for Teachers'. International Journan lof Educ a tio nalRe se archand Te chnolog y. 2010.

[10] G. Garcia. "Academic Performance as Determinant to Pass the Licensure Examination for Teachers". International Journal of Educational Research and Technology. Retrieved from www.soeagra.Original Article com/ijert/ijert.htm. 2010.

[11] A.,Young, A., \& P. Willson, P. "Predicting NCLEX-RN success. CIN: Computers, Informatics, Nursing, 30(1), 55-60.2012.

[12] E. Zweighaft, "HESI Over Time: What the Research Demonstrates and Applications to Improving". Podium presentation at the 2016 Elevate Outcomes with HESI Conference. Las Vegas, Nevada, 2016.

[13] S. G. Poorman and E. J. Martin, "The role of nonacademic variables in passing the National Council Licensure Examination," J. Prof. Nurs., vol. 7, no. 1, pp. 25-32, 1991.

[14] M. S. Chen, J. Han, and P. S. Yu, "Data mining: An overview from a database perspective," IEEE Trans. Knowl. Data Eng., vol. 8, no. 6, pp. 866-883, 1996. 


\section{International Journal of Advanced Research in Computer and Communication Engineering}

Vol. 8, Issue 4, April 2019

[15] V. Ramesh, P. Parkavi, and P. Yasodha, "Performance Analysis of Data Mining Techniques for Placement Chance Prediction," Int. J. Sci. Eng. Res., vol. 2, no. 8, pp. 1-7, 2011.

[16] S. Yadav, B. Bharadwaj, and S. Pal, "Data mining applications: A comparative study for predicting student's performance," Int. J. Innov. Technol. Creat. Eng., vol. 1, no. 12, pp. 13-19, 2012.

[17] C. M. Zahn, A. Saguil, A. R. Artino, T. Dong, G. Ming, J. T. Servey, E. Balog, M. Goldenberg, and S. J. Durning, "Correlation of National Board of Medical Examiners Scores with United States Medical Licensing Examination Step 1 and Step 2 Scores," Acad. Med., vol. 87, no. 10, pp. 1348-1354, Oct. 2012.

[18] Zupan et al. Orange and Decisions- at-Hand: Bridging Predictive Data Mining and Decision Support. [Online]. Available: http://wwwai.ijs.si/MarkoBohanec/pub/iddmorng.pdf

[19] J. Pascua, and J. Navalta, "Determinants of L.E.T. Performance of the Teacher Education Graduates in a State University". JPAIR Multidisciplinary Journal. Volume 6. 2012

[20] B. Duckor, K. Castellano, K. Téllez, D. Wihardini, and M. Wilson, "Examining the Internal Structure Evidence for the Performance Assessment for California Teachers: A Validation Study of the Elementary Literacy Teaching Event for Tier I Teacher Licensure". $J$ o $u$ r $n$ a $l$ of Te a che rEd u c a tion. d o i : 10.1177/0022487114542517.2014.

[21] M. Chapple. Regression. [Online]. Available: http://databases.about.com/od/datamining/g/regression.htm

[22] H.L. Lee, C. Park, Agent and Data Mining Based Decision Support System and its Adaption to a New Customer Centric Electronic Commerce, , Expert Systems With Applications, 25, 4, pp. 619-635, 2003 